\title{
$\mathrm{rHH}$
}

\section{FROM ANCIENT TEXTS TO MAPS (AND BACK AGAIN) IN THE DIGITAL WORLD. THE DIGILIBLT PROJECT}

\section{DE LOS TEXTOS ANTIGUOS A LOS MAPAS (Y VICEVERSA) EN EL MUNDO DIGITAL. EL PROYECTO DIGILIBLT}

\author{
Alice Borgna \\ Università degli Studi del Piemonte Orientale \\ alice.borgna@uniupo.it
}

\begin{abstract}
Greek and Latin have played a vigorous role in the intellectual life of the West, but today, according to recent statistics, this role seems to be in danger. This paper suggests how the interaction between Classics and Digital Humanities can help in reversing this negative trend: starting from the case-study of DigilibLT, Digital Library of Late Antique Latin Texts, I will explain some aspects of the building process of a digital library and show how a digital project can start a virtuous circle able not only to revive the Classics Programs in Universities, but also to generate new projects and, consequently, new digital culture.
\end{abstract}

Keywords: DigilibLT. Latin Prose. Digital Libraries. Late Antiquity. Collaboration.

\section{Resumen}

Los clásicos han jugado un papel vigoroso en la vida intelectual del Occidente, pero hoy en día, de acuerdo con estadísticas recientes, este papel parece estar en peligro. Este artículo sugiere cómo la interacción entre los clásicos y las Humanidades Digitales puede ayudar a revertir esta tendencia negativa: a partir del estudio de caso de DigilibLT, Digital Library of Late Antique Latin Texts, voy a explicar algunos aspectos del proceso de construcción de una 
biblioteca digital y mostrar cómo un proyecto digital puede iniciar un círculo virtuoso capaz no sólo de revivir los estudios clásicos, sino también de generar nuevos proyectos y, en consecuencia, nueva cultura digital.

Palabras clave: DigilibLT. Prosa latina. Bibliotecas digitales. Antigüedad tardía. Colaboraciones.

\section{INTRODUCTION}

Greek and Latin have played a central role in the intellectual life of the West for a long time, but recent statistics suggest this role is now in jeopardy. Current economic realities have placed Classics in a state of deep crisis, and the job market increasingly rewards graduates whose curricula vitae demonstrate proficiency more in new technical skills than in Language and Literature. It is nevertheless difficult to maintain the balance between encouraging these now-unavoidable changes and the understandable desire to avoid distorting the discipline.

If the world increasingly poses questions about the future of both Digital Humanities and the Humanities in general, a digital project can serve as a productive model. The paper starts from the case-study of DigilibLT, Digital Library of Late Antique Latin Texts ${ }^{1}$, and by showing how the creation of a database can spawn new philological projects, it supports the common intuition that investing in young scholars, training, cooperation, and open access can lead to a flourishing of the humanities, and especially classics, in the digital age.

\section{A CASE STUDY: DIGILIBLT}

The Digital Library of Late Antique Latin Texts was officially established on March $1^{\text {st }}$, 2010, at the Department of Humanities, University of Eastern Piedmont, thanks to funds that Regione Piemonte provided to support research in Humanities and Social Sciences ${ }^{2}$.

The digital library publishes prose texts that were written in Latin in late antiquity. The texts are annotated according to XML-TEI standards and are offered free of charge to the public for reading and research. DigilibLT also offers a complete canon of authors and works, including detailed information on the critical editions on which the digital texts are based, and

\footnotetext{
${ }^{1}$ See http://digiliblt.lett.unipmn.it/index.php?lang=en.

${ }^{2}$ Raffaella Tabacco (Full Professor of Latin, University of Eastern Piedmont) and Maurizio Lana (Senior Lecturer in Library and Information Science) lead the team. The University of Turin, a cosponsor of the project, participates with a second research unit coordinated by Ermanno Malaspina (Assistant Professor of Latin) and Andrea Balbo (Senior Lecturer in Latin). For the full team, including collaborations, see http://digiliblt.lett.unipmn.it/gruppo.php.
} 
listing, if applicable, any editorial changes that deviate from those critical editions. Typographical errors, whenever they were found, are also corrected. Search windows are designed to allow users to search the entire collection of texts, a selection of texts (e.g. limited by author, period, or type of text), or individual authors/works. Texts can be downloaded freely in different formats (TXT, TEI, PDF, EPUB). The library also provides short encyclopedic entries on late-antique authors and works, bibliographies, and canon entries. Finally, DigilibLT includes the full text of relevant modern scholarly works that are in the public domain as well as recent monographs whose legal owners granted us permission to reproduce them ${ }^{3}$.

\subsection{Why Late Antiquity?}

The information revolution that has recently affected all fields of study -including those like Classical Philology that often employ traditional approaches-continues to evolve at a rapid pace. Many textual databases originally born on CD-ROM have now been transferred to the web, despite the difficulty that such translations often pose; indeed, one of the great challenges of the contemporary world is the rapid obsolescence of technological standards. In addition, putting digital libraries and databases online raises substantive issues about open access and makes it imperative for scholars to find a way to coordinate their resources and collaborate on projects as much as possible. Another consequence of the rapid spread of global internet usage is the push to create an online presence for all relevant material, since failure to do so creates a gap that can greatly hinder scholarly research ${ }^{4}$. This was the case for Late Antique Latin Literature, which until a few years ago was only available online in fragmentary and disorganized form, an obvious reflection of the lower regard in which it was often held even in paper-based systems.

This must be contrasted with the treatment of Latin Literature composed through the second century A.D. Very early in the digital revolution, the Packard Humanities Institute (PHI) created a highly successful database (first on CD-ROM and now online) that spread rapidly among philologists, significantly changing their research habits by offering easy access to these texts. With just a few clicks of the keyboard, users can find all recurrences of a word or collocation either across the whole corpus or in sub-sets of it (author, work, or specific texts defined by the user) and also export and save their results ${ }^{5}$. The electronic tools made available by the $\mathrm{PHI}$, in other words, saved long hours in the library bent over lexicons and

\footnotetext{
${ }^{3}$ On the various aspects of DigilibLT, see the articles published in recent years by the project leaders: Lana (2011: 281-300; 2012b: 134-150; 2012c: 40-64), Tabacco (2014: 3-17; 2016), and Mosca and Musso (2016: 143-160).

${ }^{4}$ Even the Thesaurus Linguae Latinae (with which DigilibLT has communicated profitably) does not offer a complete cataloguing of the works from the mid-second century onwards.

${ }^{5}$ Moreover, the PHI CD-ROM for many years was a proprietary (and quite expensive) database, and running it required the installation of specific software such as Musaios (paid) or Diogenes (free).
} 
concordances, even allowing scholars to conduct such research from home. The CD-ROM of the PHI ends with the second century A.D., however, cutting the authors and texts of Late Antiquity out of this authoritative digital version.

As a result, the Latin texts of Late Antiquity have gradually appeared online in different forms, often in collections dedicated to specific genres. For example, the site Musisque Deoque is dedicated to Latin poetry from its origins to the Italian Renaissance ${ }^{6}$. Christian authors were likewise given a digital catalogue at a relatively early date: in 1994 Cambridge University Press published a CD-ROM containing Migne's complete edition of the Patrologia Latina, a tool that can still be accessed online for a fee ${ }^{7}$. Yet free versions of those texts also exist online: in fact, the huge collection of the Documenta Catholica Omnia offers old editions of Migne that are reproduced anastatically, keeping the original typesetting and page numeration; this solution unfortunately precludes the use of advanced search functions ${ }^{8}$. This shortcoming is not faced by the Latin Series of the Corpus Christianorum ${ }^{9}$, which is contained in the online database of the Library of Latin Texts, but this resource is accessible only by paying a considerable subscription fee ${ }^{10}$. BIA-Net (Bibliotheca luris Antiqui online) is a wellknown project devoted specifically to legal texts ${ }^{11}$, while grammatical texts have been available in digital form since the almost prehistoric times (from the Computer Technology point of view, i.e. the early 1970s) through the work of Nino Marinone, professor of Latin at the University of Turin, in collaboration with the Institute of Computational Linguistics of CNR in Pisa ${ }^{12}$. The result of this collaborative approach was a CD-ROM (GL-CD), unfortunately never marketed, which contained the whole corpus of grammatical works collected in the Heinrich Keil's seven volumes edition of the 1800s with updates from more recent editions whenever they were available. Precisely because this work dates back to pioneer times in Computer Science, however, it suffers from the problem of rapid obsolescence to which digital media are currently exposed. In fact, apart from being incompatible with all current operating systems, the GL-CD presents difficulties even in the simple extraction of its contents. As a partial solution, in 2006

\footnotetext{
${ }^{6}$ Musisque deoque (http://www.mqdq.it) was developed by a group of Italian Universities (Venice, Calabria, Padua, Parma, Perugia and Naples) under the general coordination of Paolo Mastandrea (University of Venice). It is a very useful tool, where the user can read the texts or search them through an advanced form. From a philological point of view, Musisque deoque is especially useful because it lists the most important textual variants found in manuscripts. See Mastandrea (1999: 451-457), Mastandrea and Spinazzè (2011).

${ }^{7}$ See http://pld.chadwyck.com.

${ }^{8}$ See http://www.documentacatholicaomnia.eu.

${ }^{9}$ See $\mathrm{http}: / /$ www.brepols.net/Pages. This database, which is the development and expansion of the CETEDOC Library of Christian Latin Texts, is divided into an Original Series (Series A) and a Series B, started in 2009. It contains, among other things, the versions of Latin texts through the $2^{\text {nd }} \mathrm{c}$. AD that are published in the Bibliotheca Teubneriana Latina. With regard to Late Antiquity, LLT-O includes the patristic authors $\left(3^{\text {rd }}-8^{\text {th }} \mathrm{c}\right.$. $)$ and some significant pagan works (Ammianus Marcellinus, the Scriptores Historiae Augustae, Claudian, Macrobius, Martianus Capella, the Panegyrici Latini, the Grammatici Latini, Optatianus Porfirio, the Herbarium of Ps.-Apuleius, and the Mulomedicina Chironis), also taken from Teubner editions published before 1980.

${ }^{10}$ See http://www.digento.de/titel.

${ }^{11}$ See http://www.lex.unict.it/cir/\#bianet.

12 See Lomanto (1980: 113-270), Lomanto and Marinone (1994: 55-74).
} 
the whole corpus was uploaded to the Corpus Grammaticorum Latinorum website ${ }^{13}$, a tool that allows a free online consultation, but not the ability to download texts or perform advanced queries. DigilibLT has also begun publishing the grammatical texts contained in the Marinone's $G L-C D$ in order to provide greater access to the database together with the capacity for search and download that are afforded by DigilibLT's underlying architecture ${ }^{14}$.

Until few years ago, then, the Internet offered scholars of Late Antique Latin texts only a few fragmented resources. Most of these were inaccessible or behind a paywall, resulting in a situation that was challenging even for the study of pagan prose, an area that had never known an authoritative digital library ${ }^{15}$.

\section{OPENING THE DOOR OF A DIGITAL LIBRARY}

\subsection{The Canon}

Construction of the digital resource began with devising a list of all the works and authors to include in the library. The DigilibLT canon, written by research team member Simona Musso, contains a list of late-antique authors of non-Christian prose works, together with their current editions of reference. It includes about four hundred entries that are not only available and downloadable as a standalone file, but can also be searched by author, work, alphabetically, or by century.

By way of example, the image below shows the result of a search for authors whose names start with $C$. The list also includes anonymous works, here printed in italics.

\footnotetext{
${ }^{13}$ See http://kaali.linguist.jussieu.fr/CGL/text.jsp.

${ }^{14}$ The list is not meant to be prescriptive: it merely presents the choices that were made by the DigilibLT library and is meant to be open for scholars' collaboration.

${ }^{15}$ See Tabacco (2014: 5-6) and Tabacco (2016: 125-142). For a more detailed overview of the tools for classical languages currently available online see Balbo (2013: 53-68; 2014: 9-14) and Crane (2015).
} 


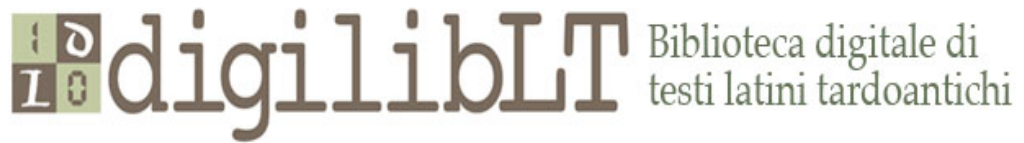

\section{UPQ FPricoive}

\begin{tabular}{|l|}
\hline \multicolumn{1}{|c|}{ Search } \\
\hline Searchable works \\
Advanced search \\
Search the bibliography \\
\hline Browse and download \\
\hline Works \\
Authors \\
\hline Bibliography \\
\hline By date \\
II III IV V VI VII \\
Uncertain date \\
All the authors \\
\hline By name \\
A B CD E F G H I L M N O \\
P Q R S T V \\
All the authors \\
\hline Other resources \\
\hline Modern studies on late \\
antiquity \\
Canon of late-antique \\
authors \\
Fonts and software to \\
download \\
Download texts \\
\hline
\end{tabular}

Authors and anonymous works starting with the letter C

1. Caelius Aurelianus - saec. IV-V

2. Calcidius - saec. IV ex./V in.

3. Calpurnius Flaccus - saec. II (dub.)

4. Caper (Ps.) - saec. II

5. Cassiodorus - m. 580

6. Cassius Felix - saec. v

7. Censorinus - saec. III

8. Censorinus (ps.)

9. Cetius Fauentinus - saec. III ex./IV in.

10. Charisius, Flauius Sosipater - saec. IV

11. Chiron - saec IV (sec.)

12. Chronographus anni CCCLIV - saec. IV

13. Cledonius - saec.V

14. Clodianus - saec. V-VI

15. Collatio Alexandri et Dindimi - saec. V (dub.)

16. Commenta Bernensia in Lucanum - saec. IV-V (dub.)

17. Commonitorium Palladii de uita Bragmanorum - saec. $V$ (dub.)

18. Consentius - saec. $\mathbf{V}$

19. Constantinus (Flavius Valerius Constantinus) - saec. III-IV

20. Cornelius Labeo - saec. III

Figure 1. Result of a search for authors whose names start with $C$.

Searching by work yields even more information, since it indicates the presence of texts in the database and uses different icons to specify formats in which they are available. In fact, after completing a free registration on the site, all of these texts can be read online ${ }^{16}$ or downloaded in various file types (TXT, TEI, PDF, EPUB) in order to accommodate individual working and readings habits. Following the Open Source philosophy, all texts are distributed under a Non-Commercial Creative Commons License (ShareAlike 3.0). This will make it easier for new research to pick up on the advances of earlier projects in keeping with the sharing is caring ethos that will be described at greater length below ${ }^{17}$. The following figure, for example, shows the result of a search for works starting with $E$.

\footnotetext{
${ }^{16}$ Information is only collected for statistical purposes.

17 See Lana (2012a: 48-64), on the collaborative aspect of DigilibLT.
} 


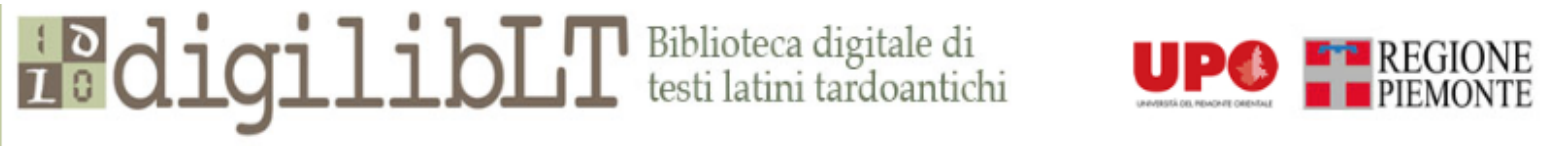

Home $\mid$ The project $\mid$ News $\mid$ Late antiquity on the web $\mid$ Help $\mid$ Contacts and feedback $\mid$ Reserved area $\mid$

A $\mathrm{A}$ A 1 米

\begin{tabular}{|l|}
\hline \multicolumn{1}{|c|}{ Search } \\
\hline Searchable works \\
Advanced search \\
Search the bibliography \\
\hline Browse and download \\
\hline Works \\
Authors \\
Bibliography \\
\hline By date \\
II III IV V VI VII \\
Uncertain date \\
All the works \\
\hline By name \\
A B C DEF G H I L M N O \\
P Q R S T V \\
All the works \\
\hline \multicolumn{1}{|c|}{ Other resources } \\
\hline Modern studies on late \\
antiquity \\
Canon of late-antique \\
authors \\
Fonts and software to \\
download \\
Download texts \\
\hline
\end{tabular}

Select the preferred order (see on the left-hand side)

by date (by century, of uncertain date, or complete list)

by name (by letter, or complete list)

\section{Works starting with the letter $E$}

1. Elementa uersio M - saec. VI

2. Elementa uersio $\mathrm{V}$

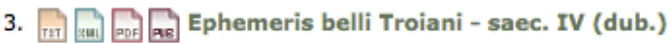

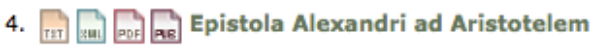

5. 国 不

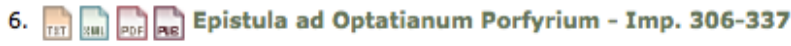

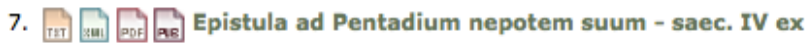

8. Epistula ad Pullium Natalem (apud Marcellum medicum) - ante saec. V

9. Epistula ad Valentinianum imperatorem - saec. IV ex

10. TAT

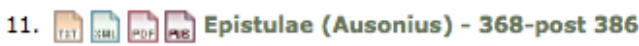

12. Fit

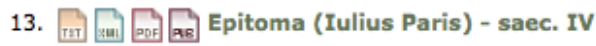

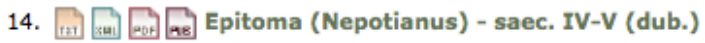

15. Fit

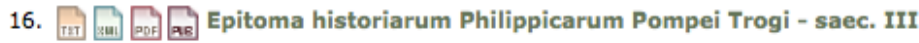

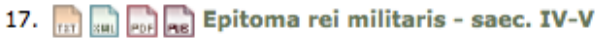

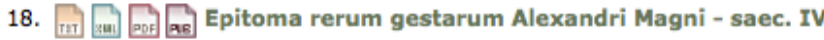

19. Epitome anonyma (quae gynaecia uocatur) recensio Ba - saec. IV ex

20. Epitome anonyma (quae gynaecia uocatur) recensio $\mathrm{C}$ - saec. IV

\section{$123 m$}

Figure 2. Result of a search for works starting with $E$.

The top button on the left column provides a detailed list of all the works currently available for searching and downloading, divided by century. Special updates on the homepage report each new addition. 


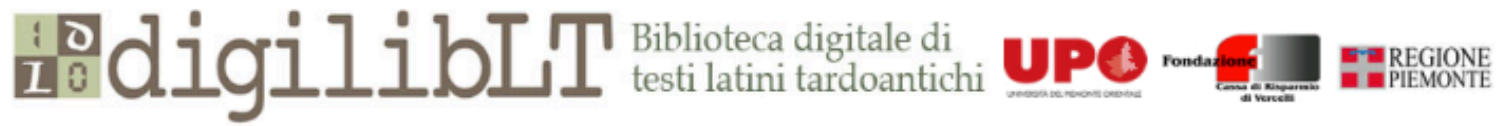

Home $\mid$ The project $\mid$ News $\mid$ Late antiquity on the web $\mid$ Help | Contacts and feedback | Reserved area |

A $A$ D त्राए

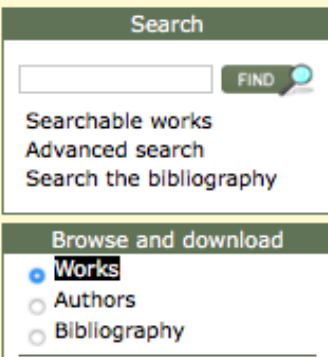

By date

II III IV $V$ VI VII VIII

Uncertain date

All the works

By name

A BCDEFGHILMNO

PQRSTV

All the works

Other resources

Modern studies on late

antiquity

Canon of late-antique

authors

Fonts and software to

download

Download texts

Additional proponent

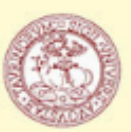

Select the preferred order (see on the left-hand side)

by date (by century, of uncertain date, or complete list)

by name (by letter, or complete list)

Works VI century

1. Ad Eunapium

2. Ad Theodoricum regem Francorum epistula de obseruatione ciborum

3.

4. $\mathrm{Fin}$. $\mathrm{Fen}$ Analytica priora Aristotelis latine uersa

5. quaedam seorsum editae)

6. ordine generis Cassiodororum

7. Anecdotum medicum

8. Aphorismi

9. $\mathrm{Tr}$ Ars de uerbo

10. Tir

11.

12. Tit Chronica (Cassiodorus)

13. $\mathrm{Tin}$ 国 Chronica (Isidorus)

14.

15. Tim Collatio Alexandri et Dindimi

16. Commentaril in Ciceronis Topica

17. Commentaril in Iibrum Aristotelis Peri hermenelas prima editio

18. Commentaril in Iibrum Aristotelis Peri hermeneias secunda editio

19.

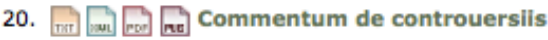

Figure 3. List of the sixth century works that are currently available.

In addition to ancient texts, it is also possible to download the full text of modern scholarly works in the public domain which are still of interest for the study of Late Antiquity. The most significant group consists of the works on late antiquity authored by Italo Lana, among the first Italian classicists to pay special attention to Late Antiquity and unforgotten teacher of many of the project members. Moreover, a good number of these books, born as university lecture notes, not only today can be found with difficulty, but the rapid process of disintegration of the acid paper they were printed on is threatening their very survival.

In addition, DigilibLT also provides the full text of recent monograph whenever the legal owners of the publication rights grant us permission.

\subsection{Searching the Database}

The DigilibLT user can consult the corpus using either a simple or an advanced search. The first of these can be accessed on the homepage, and allows searches for specific words or inflected forms of a given root (using an asterisk after the root, e.g. amiciti*). The formatting 
utilized for DigilibLT texts ${ }^{18}$, however, also allows for more refined queries. Accessible from the advanced search form, these allow the user to search the entire corpus or user-defined subsections of it (e.g. single works, specific genres, centuries). Asterisks and Boolean operators make it possible to combine searches of multiple words with variable endings; proximity searches and queries by text section are also possible (e.g. in the entire text, in titles, in quotations or passages written in Greek).

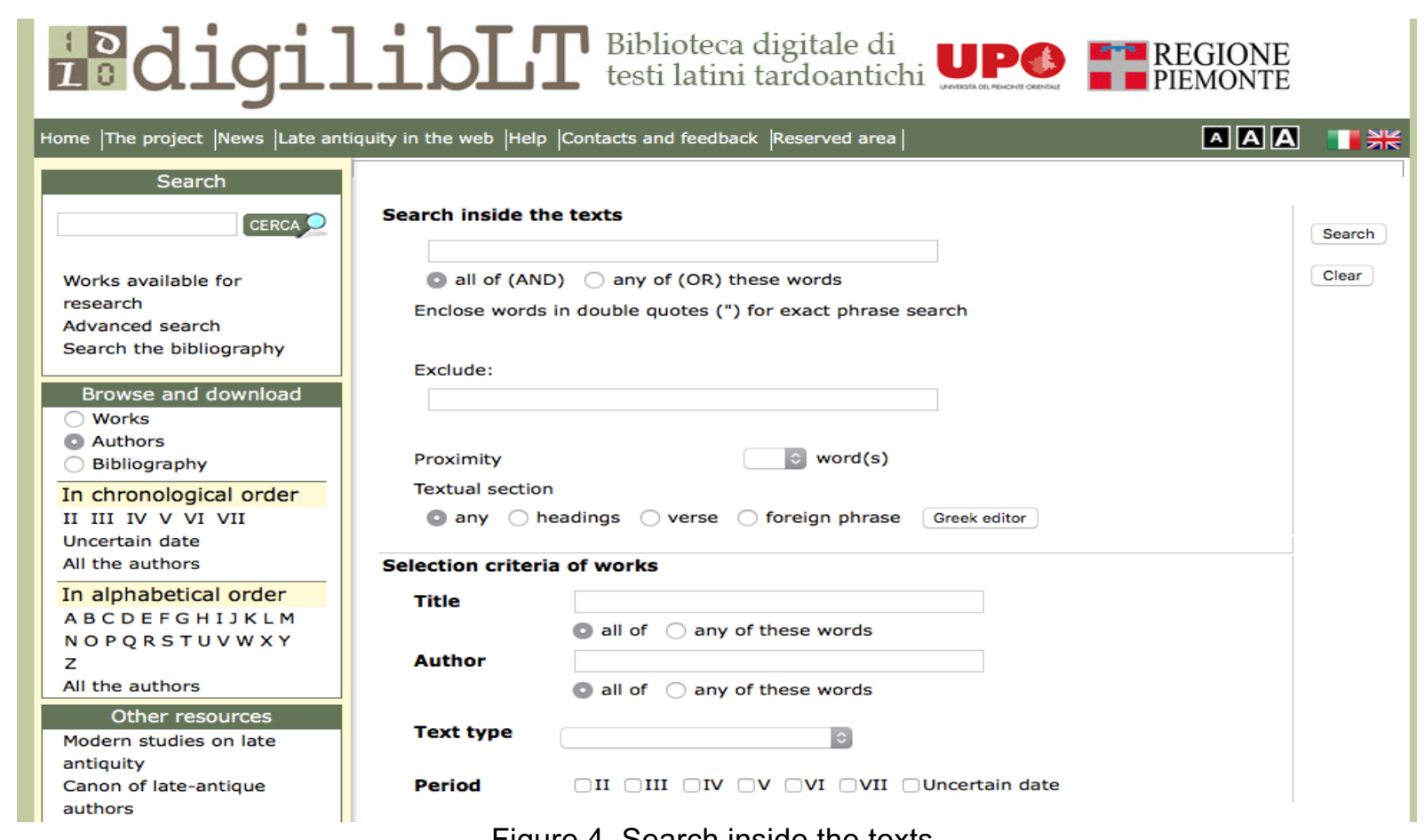

Figure 4. Search inside the texts.

The search results provide occurrences of the selected term(s) in individual works. Moreover, each entry furnishes links to the full text of the work and to a concordance (KWIC: Key Word in Context) that is viewable either in list form or in side-by-side format.

\footnotetext{
${ }^{18}$ For an exhaustive description of the mark-up chosen by DigilibLT team, see Musso (2014: 161-184). A document (by Simona Musso) describing the standards used for transcription and text encoding is available to DigilibLT users at http://digiliblt.lett.unipmn.it/upload/docs/note di trascrizione_e di_codifica.pdf.
} 


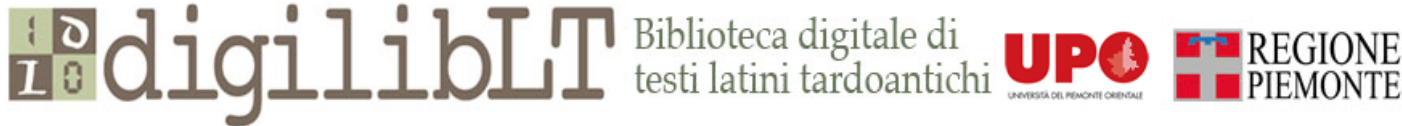

Home $\mid$ The project $\mid$ News $\mid$ Late antiquity in the web | Help | Contacts and feedback| Reserved area

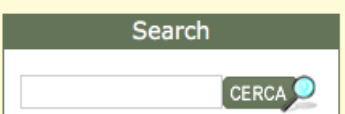

Works available for

research

Advanced search

Search the bibliography

Browse and download

Works

- Authors

Bibliography

In chronological order

II III IV V VI VII

Uncertain date

All the authors

In alphabetical order

A B CDEFGHIJKLM

NOPQRSTUVWXY

All the authors

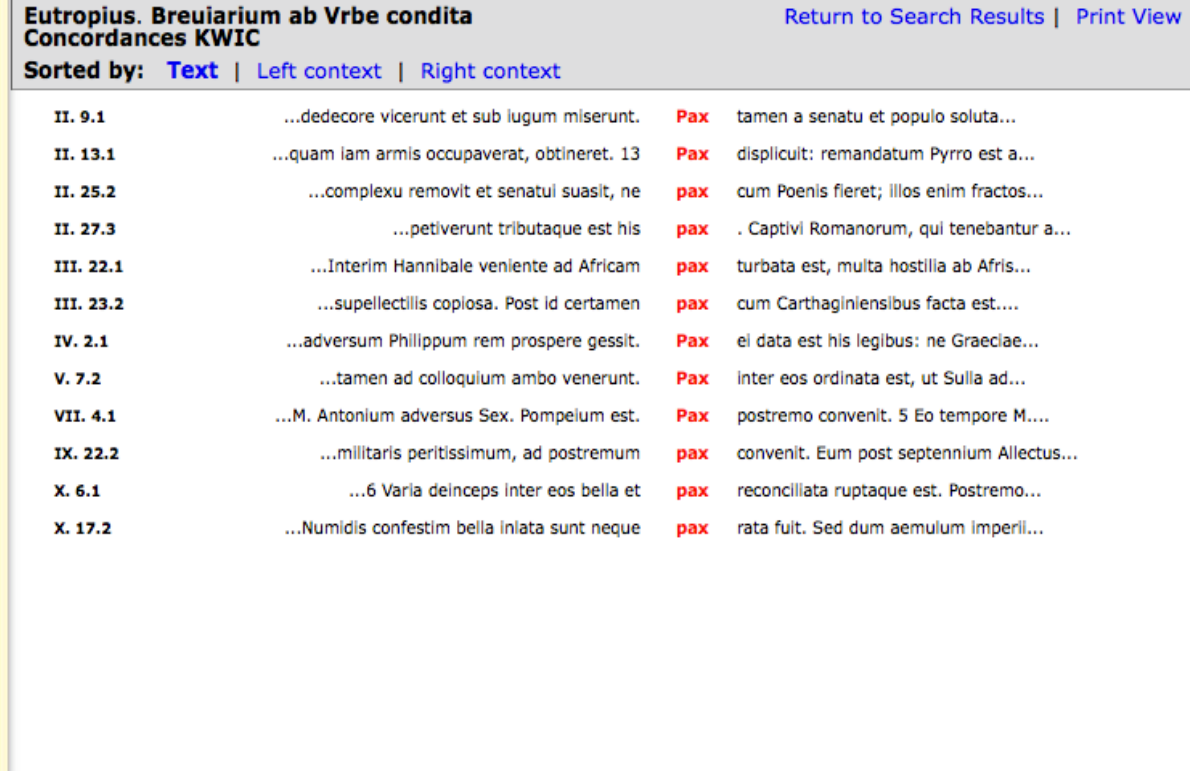

(t) condita Sorted by: Text | Left context | Right context

Figure 5. Concordance, in list form, of instances of pax in Eutropius' Breviarum Ab Urbe Condita.

\subsection{A Real Working Environment: Short Entries and Bibliography}

Given the scarcity of late antique texts online, the DigilibLT project is useful to both scholars and general readers wishing to learn more about this (less familiar) literary period. The canon developed by the project includes many texts that have not enjoyed the same level of detailed study given to classical Latin texts; indeed, even the names of these late antique authors are often unknown to the general public. The library consequently provides short encyclopedic entries on each author and text. These are composed by well-regarded experts in the field of Late Antiquity and give special attention to the interpretive debates that have defined scholarship to this date ${ }^{19}$. In order to make the library more useful to international users, the entire website -including all encyclopedic entries- has been translated into English by specialists.

\footnotetext{
${ }^{19}$ The senior members of the group wrote most of these introductions to individual authors and work entries, which are often the result (albeit condensed) of research developed over the years. Other entries were produced by collaborators who were invited to participate as renowned experts on the texts in question.
} 


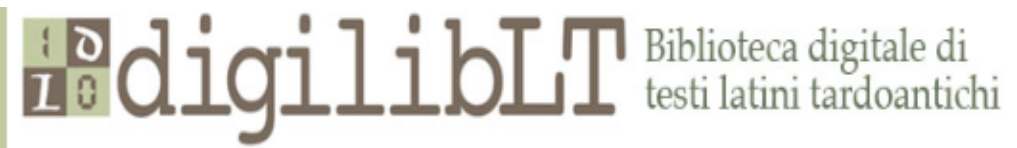

\begin{tabular}{l}
\hline \multicolumn{1}{|c|}{ Search } \\
\hline Searchable works \\
Advanced search \\
Search the bibliography \\
\hline Browse and download \\
Works \\
Authors \\
\hline Bibliography \\
By date \\
II III IV V VI VII \\
Uncertain date \\
All the authors \\
\hline By name \\
A B C D E F G H I L M N O \\
P Q R S T V \\
All the authors
\end{tabular}

\begin{tabular}{|l|}
\hline \multicolumn{1}{|c|}{ Other resources } \\
\hline Modern studies on late \\
antiquity \\
Canon of late-antique \\
authors \\
Fonts and software to \\
download \\
Download texts \\
\hline
\end{tabular}

Additional proponent

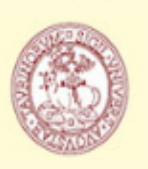

Epitoma historiarum Philippicarum Pompei Trogi

Iustinus

Author Details

saec. III

\section{Available downloads}

\section{TXT TEI PDF E.PUB}

\section{CATALOGUE ENTRY}

Reference edition:

M. Iuniani Iustini Epitoma historiarum Philippicarum Pompei Trogi; accedunt Prologi in Pompeium Trogum, edidit Otto Seel, Stutgardiae 1972 (Bibliotheca Scriptorum Graecorum et Romanorum Teubneriana).

Justin's Epitoma historiarum Philippicarum is a late epitome of a longer work narrating universal history. The original work was written by Pompeius

Trogus, probably in the age of Augustus or Tiberius. The Preface informs the readers about the content of Trogus' work and Justin's epitomising technique. Justin states that Pompeius Trogus 'wrote a history of Greece and of the whole word in Latin so that one could read the history of Greece in our language, just as it is possible to read our history in the Greek language'; he

Preliminary steps: Alice Borgna

Text fitting: Alice Borgna

TEI code: Alice Borgna

Digital edition by the digilibLT group - Università degli Studi del Piemonte Orientale

\section{Back to list}

Figure 6. Example of an author short entry in DigilibLT.

As can be seen in Figure 6, DigilibLT includes a constantly updated bibliography that is visible on the right column of the pages containing entries on authors or works. It is also accessible from the home page, where a link leads directly to the advanced search form ${ }^{20}$.

${ }^{20}$ Queries can be conducted according to numerous terms: modern author, ancient author, title, ancient work, publication type (i.e. edition, lexicon, miscellany, monograph), journal title, relevant keywords about the content (i.e. authenticity, biography, exegesis, legacy, prosopography), year of publication, relevant centuries. 


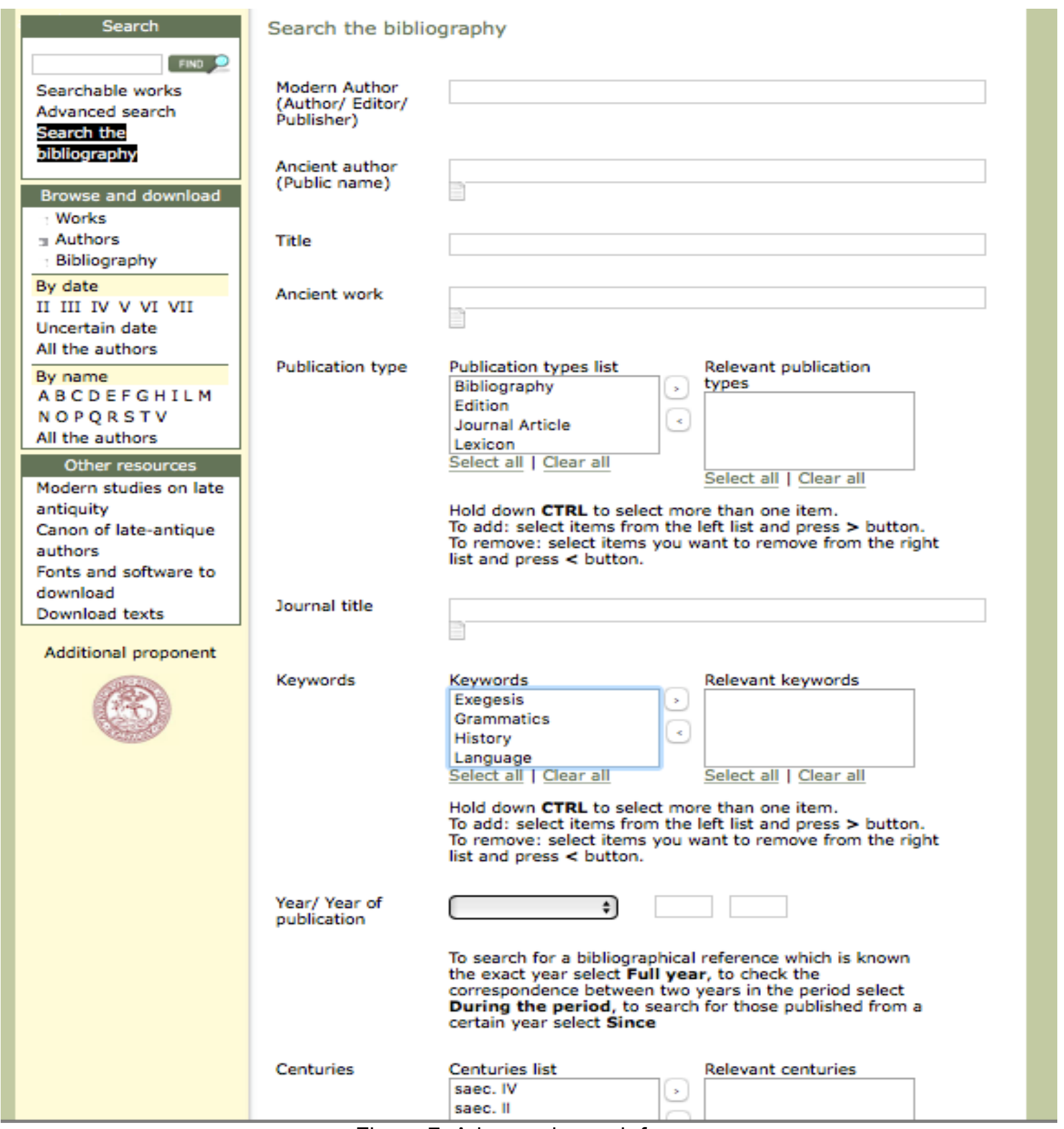

Figure 7. Advanced search form. 


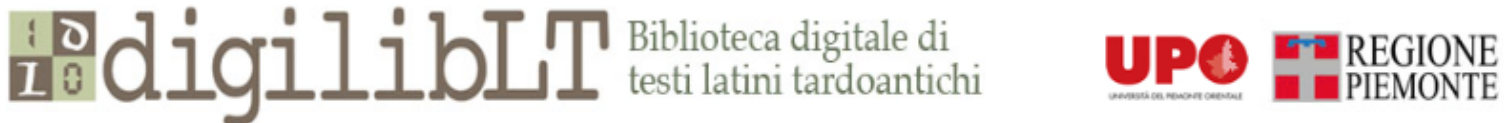

\begin{tabular}{|l|}
\hline \multicolumn{1}{|c|}{ Search } \\
\hline \\
\hline Searchable works \\
Advanced search \\
Search the bibliography \\
\hline \multicolumn{1}{|c|}{ Browse and download } \\
\hline Works \\
Authors \\
Bibliography \\
\hline By date \\
II III IV V VI VII \\
Uncertain date \\
All the authors \\
\hline By name \\
A B C D E F G H I L M N O \\
P Q R S T V \\
All the authors \\
\hline \multicolumn{1}{|c|}{ Other resources } \\
\hline Modern studies on late \\
antiquity \\
Canon of late-antique \\
authors \\
Fonts and software to \\
download \\
Download texts \\
\hline
\end{tabular}

Search the bibliography

Back to search form

Search Results:

Rows per page $50 \quad$ Order by Modern Author 17 matches found

1. Baudou, Alban

Censorinus et le saeculum pisonien

Bibliography in reference to Ancient author:

1. Censorinus saec. III

2. Cataudella $Q$.

Sopra due luoghi di Censorino

Bibliography in reference to Ancient author:

1. Censorinus

saec. III

3. Cristante L.

Appunti su Pseudo Censorino frg. 9-11 (con una proposta di edizione)

Bibliography in reference to Ancient author:

1. Censorinus (ps.)

4. Eilers, Claude

The Date of Augustus' Edict on the Jews (Jos. AJ 16.162-165) and the Career of C.

Marcius Censorinus

Bibliography in reference to Ancient author:

1. Censorinus saec. III

5. Farmhouse Alberto P. Paniagua D.

Ways of Approaching Knowledge in Late Antiquity and the Early Middle Ages.

Schools and Scholarship (Studia Classica et Medievalia 8)

Bibliography in reference to Ancient author:

Figure 8. Results of a search on Censorinus, conducted by modern author and organized alphabetically.

\section{INVESTING IN YOUTH}

As noted above, DigilibLT had to be designed from the ground up since there was not any pre-existing digital database of these texts, even in prototype form. One result of this challenge, however, was that the team reflected not only on technical issues, but also on the objectives of the project and the philosophy that would guide it. A number of important decisions resulted from this process, with one of the biggest being that we would keep every step of text-processing (digitization, OCR correction, mark-up, and upload) within the research group. Choosing not to outsource such work to specialized forms led to a marked enlargement of the group at multiple levels as we enlisted the aid of both university professors and promising students ${ }^{21}$.

\footnotetext{
${ }^{21}$ See Musso (2014: 51-87) for a detailed presentation of the DigilibLT process of acquisition and correction of the texts. On involving students in digital projects see, inter alios, Blackwell and Martin (2009) and Hayles (2012: 52).
} 
In this sense, DigilibLT represents a real investment in young scholars. Promising students have been involved in all phases of the library's development, operating under varying degrees of supervision in accordance with their own levels of expertise and experience.

Current economic realities have placed the humanities in a state of deep crisis, and the job market increasingly rewards humanists (including classicists) whose curricula vitae demonstrate proficiency not only in Latin and Greek language and literature, but also in new technical skills ${ }^{22}$. It is nevertheless difficult to maintain the balance between encouraging these now-unavoidable changes and the understandable desire to avoid distorting the discipline. The results of the path forged by DigilibLT have so far been positive and encouraging, as numerous students working with the group have developed skills in Digital Humanities while still acquiring deep familiarity with the discipline's textual content. Under the guidance of supervisors, graduate students —and some especially promising undergraduates — have been responsible preparing one or more texts. In addition to helping them to take their first steps into Digital Humanities, this activity necessarily entailed a significant expansion of their Latin reading skills since few classes even at the university level give significant attention to the grammar of Late Antique Latin ${ }^{23}$. Furthermore, adhering to a philosophy that aimed less at the mere search for manpower and instead sought to create new competencies, students have always enjoyed the chance to contribute to the scholarly aspects of the library, for example by collecting preparatory notes for the entries on authors and works or working on a critical selection of the bibliography. As already mentioned, all the material produced by these students has been checked by project leaders in a multi-layered control system designed to ensure a uniformly high quality of content for publication on the website.

Doctoral students and post-docs naturally benefited from this investment in youth. Their philological research has progressed together with an intensive training in Digital Humanities, gradually perfected through participation in workshops and advanced courses in Italy and abroad. Indeed, a firm conviction of DigilibLT has been that even the mark-up of a digital text represents an aspect of these new scholarly editions that philologists must not delegate to computer scientists ${ }^{24}$. This philosophy of inclusion and openness yielded not only traditional

\footnotetext{
${ }^{22}$ See Crane (2014), with further bibliography.

${ }^{23}$ Here it is also worth mentioning the collaboration between DigilibLT and the Thesaurus linguae Latinae. One of its contributors, Johann Ramminger, used an automatic parsing of the texts to isolate a number of atypical forms. In some cases, further analysis revealed these to be late forms that were previously unrecognized. Such discoveries offer clear evidence of the value added by the DigilibLT corpus in the field of the history of Latin language.

${ }^{24}$ See Tabacco (2014: 7): "Il latinista può essere tentato da una delega all'esperto di informatica [...] ma tale delega non è opportuna perché può produrre uno strumento poco utile o peggio sviante per la comunità scientifica e per suo tramite per la stessa collettività destinataria di forme di disseminazione del sapere mediante prodotti editoriali e divulgativi di vario genere. Ciò è vero in particolare per testi difficili e spesso poco studiati, quale è il corpus delle opere profane tardo latine [...] solo la competenza di un latinista può impostare, affrontare e guidare alla soluzione i problemi di codifica informatica che ad ogni passo si presentano e che dipendono sia dalla complessità dei testi medesimi sia dalla eterogeneità delle scelte formali operate da editori diversi in un arco di tempo spesso anche molto ampio; ciò beninteso quando si vogliano predisporre per la ricerca informatizzata testi capaci di trasmettere in modo corretto le informazioni risultanti dal lavoro filologico di chi su di essi ha operato".
} 
conferences $^{25}$, but also broader initiatives like the Summer and Winter International Schools on Digital Humanities ${ }^{26}$.

\section{FROM ANCIENTS TEXTS TO MAPS AND BACK AGAIN: DIGILIBLT AS A} STARTING POINT

DigilibLT's support of Open Access as a means of dissemination has led to active partnerships with other projects and platforms. Besides being a duty in the case of a research supported by public funding, this openness helps to combat the isolation that often afflicts the Digital Scholarship ${ }^{27}$. DigilibLT enjoys many levels of cooperation: the first and most immediate is the direct connection with users made possible by the Contacts and feedback link on the left column of the home page. The team has also developed more structured collaborations, such as an agreement recently struck with the National Central Library of Florence for including the works of DigilibLT in the national catalogue. Partnerships with other national entities are currently in an advanced stage of negotiation and will hopefully be finalized $\operatorname{soon}^{28}$.

Yet the creation of an online database annotated according to XML-TEI standards is not in itself a noteworthy end goal; rather, our team views its completion as a starting point for new developments and projects. To date, DigilibLT has undertaken two new projects, both financially supported by Fondazione Compagnia di San Paolo ${ }^{29}$ after a competitive call: GeoLat, Geography for Latin Literature. This project will create a new database of geographical information contained in Classical and Late Antique Latin texts and allow search queries to be conducted through a geographical/cartographical interface ${ }^{30}$. TBL: Textual Bilingualism in Latin. This project will create a database of Late Antique Latin texts that show bilingualism in Greek and Latin, in order to support investigations of the linguistic phenomena that result from contact between these languages in Late Antiquity ${ }^{31}$.

\footnotetext{
${ }^{25}$ For instance, the International Conference Tecnologie moderne per le opere degli antichi (Vercelli, 8th November 2011), whose proceedings are hosted on Aevum Antiquum, N.S.11, 2011 (2014).

${ }^{26}$ Digital tools for printed critical editions (Vercelli, 13th-14th June 2013); LaTeX Winter School for critical editions (Vercelli, 29th-31st January 2014).

27 See McGann (2005: 77): "Digital scholarship -even the best of it- is all more or less atomized, growing like so many Topsies. Worse, these creatures are idiosyncratically designed and so can't easily talk to each other".

${ }^{28}$ For instance, Internet Culturale, http://www.internetculturale.it, and Cultura Italia www.culturaitalia.it.

${ }^{29}$ See http://compagniadisanpaolo.it.

${ }^{30}$ See https://goo.gl/3VRPGt (website currently relocating). GO!, the geographical ontology developed by GeoLat, aims to provide a complete and informative description of the geographical knowledge emerging from Latin literature, and to offer some minimal types of automatic reasoning which plays a central role in intelligent spatial search on the web and serves as a shared vocabulary for spatial mark-up of Web sources. At this level, the sites of antiquity will be associated with a variety of information, in particular, GPS, coordinates, as well as historical, geographical, cultural, etymological, semantic, and temporal annotations. For a detailed description of GeoLat and GO!, see Afferni (2013: 153-159), Ciotti et al. (2015) and Borgna et al. (2016: 7-18).

${ }^{31}$ See http://tbl.uniupo.it. The label textual bilingualism is to be understood as including various kind of use of Greek in Latin Literature depending on the specific degree of competence of the various authors both in spoken and written Greek. The TBL corpus has been created to study these uses and to assess both quantitatively and qualitatively the degree of bilingualism in literary texts belonging to different genres and attested across a long historical period (from the $3^{\text {rd }}$ to the $7^{\text {th }}$ A.D.). The team is annotating the TBL corpus using a specifically created TEI subset.
} 
The DigilibLT team is also planning an ambitious future project that will seek to gather Latin texts from the most authoritative digital libraries into a central repository in order to allow users to perform advanced queries on the whole universe of Latin texts, independent of genre, from its origins to the Middle Ages ${ }^{32}$.

By way of conclusion, it is useful to remember the words that John Unsworth offered to a conference in 2003 about achieving proper balance when developing new tools in the Digital Humanities:

We need (we still need) to demonstrate the usefulness of all the stuff we have digitized over the last decade and more - and usefulness not just in the form of increased access, but specifically, in what we can do with the stuff once we get it: what new questions we could ask, what old ones we could answer (Unsworth, 2003).

More than a decade later, these questions apparently remain relevant:

A tuttora, l'enfasi sembra essere stata posta prevalentemente sulla produzione, piuttosto che sull'impiego dei dati cosi prodotti, come se si trattasse soltanto di formare un immenso archivio di testi codificati, predisposti per cosi dire a futura memoria senza considerare più di tanto il problema dell'uso e delle modalità di impiego di tali risorse (Buzzetti, 2011: 39).

Still, the emphasis seems to have been placed primarily on production, rather than on the utilization of information produced in this way, as if the concern were solely with creating a massive archive of consolidated texts, prepared -as it were- for future memory, without giving any consideration to the problems that such use entails or even the ways in which such resources might be utilized.

In a world that increasingly demands the creation of perfect symbiosis between online resources, informational ontologies, and open data in order to promote the development of both Digital Humanities and the Humanities in general, DigilibLT serves as a productive model. By showing how the creation of a database can spawn new philological projects, it supports the common intuition that investing in young scholars, training, cooperation, and open access can lead to a flourishing of the Humanities in a digital age.

\footnotetext{
${ }^{32}$ The project BibLat (Bibliotheca Latina) aims to collect the Latin texts of the most authoritative digital libraries into a central repository where they are managed by an XML-aware textual database designed to allow searches whose results will refer back to the originating library.
} 


\section{BIBLIOGRAPHICAL REFERENCES}

AFFERNI, R. (2013). "The Experience of GeoLat Group about the Project DAGOClat - Digital Atlas with Geographical Ontology for Classical Texts". e-Perimetron, 8.3, 153-159. Retrieved from http://www.e-perimetron on 25/04/2017.

BALBO, A. (2013). "La nuvola greca e latina: Rete, cloud computing e antichità classica nel XXI secolo". In L'età di Internet. Umanità, cultura, educazione, F. Pagnotta (ed.), 5368. Milano-Firenze: Mondadori-Le Monnier Università.

(2014). "Tornate all'antico e sarà un progresso: prospettive didattiche per il latino in Italia nel primo scorcio del XXI secolo". In Prospettive per l'insegnamento del latino. La didattica della lingua latina fra teoria e buone pratiche, A. Balbo and M. Ricucci (eds.), 9-14. Torino: Loescher.

BLACKWELL, C. and MARTIN, T.R. (2009). "Technology, Collaboration, and Undergraduate Research". Digital Humanities Quarterly, 3.1. Retrieved from http://www.digitalhumanities.org/dhq/vol/3/1 on 20/04/2017.

BORGNA, A., CIOTTI, F., LANA, M. and TAMBASSI, T. (2016). "Ontologies and the Cultural Heritage. The Case of GO!". In Proceedings of the Second International Workshop on Semantic Web for Scientific Heritage (SW4SH 2016), I. Draelants, C. Faron Zucker, A. Monnin and A. Zucker (eds.), 7-18. Retrieved from http://ceur-ws.org/Vol1595/paper1.pdf on 20/04/2017.

BUZZETTI, D. (2011). "Oltre il rappresentare: le potenzialità del markup". In La macchina nel tempo. Studi di informatica umanistica in onore di Tito Orlandi, D. Fiormonte and L. Perrilli (eds.), 39-62. Firenze: Le Lettere.

CIOTTI, F., LANA, M. and TOMASI, F. (2015). "TEI, Ontologies, Linked Open Data: GeoLat and Beyond". Journal of the Text Encoding Initiative, 8. Retrieved from http://jtei.revues.org/1365 on 20/04/2017.

CRANE, G. (2014). "So You Want to become a Professor of Greek and/or Latin? Think Hard about a PhD in Digital Humanities". Retrieved from http://tinyurl.com/mwx6m35 on 20/04/2017.

(2015). Essays on Digital Classics and Digital Humanities. Retrieved from https://docs.google.com/document on 20/04/2017.

HAYLES, K. (2012). "How We Think: Transforming Power and Digital Technologies". In Understanding Digital Humanities, D.M. Berry (ed.), 42-66, London: Palgrave Macmillan.

LANA, M. (2011). "Un database testuale per il latino tardo". In La macchina nel tempo. Studi di informatica umanistica in onore di Tito Orlandi, D. Fiormonte and L. Perrilli (eds.), 281-300. Firenze: Le Lettere. 
(2012a). Biblioteche digitali. Un'introduzione. Bologna: Bononia University Press. (2012b). "Da una digital library del latino tardo ad un corpus globale". In Dall'informatica umanistica alle culture digitali. Atti del convegno di studi (Roma, 27-28 ottobre 2011) in memoria di Giuseppe Gigliozzi, F. Ciotti, and G. Crupi (eds.), 134-150. Roma: Digilab. (2012c). "Metodologie e problematiche per una biblioteca digitale. II caso di DigilibLT". Digltalia. Rivista del digitale nei beni culturali, 7, 40-64.

LOMANTO, V. (1980). "Lessici latini e lessicografia automatica". Memorie dell'Accademia delle Scienze di Torino. Classe di Scienze Morali, Storiche e Filologiche, vol.4, 113-270. and MARINONE, N. (1994). "Philologie et informatique: résultats et projets". Revue Informatique et statistique dans les sciences humaines, 30, 55-74.

MASTANDREA, P. (1999). "Un nuovo programma di ricerca intertestuale elettronica dedicato alla poesia classica e medievale (con un esempio di applicazione a Sedulius Scotus)". In Latin vulgaire-latin tardif 5 . Actes du $V^{e}$ colloque international sur le latin vulgaire et tardif, Heidelberg, 5-8 septembre 1997, G. Petersmann and R. Kettemann (eds.), 451457. Heidelberg: Winter.

and SPINAZZĖ, L. (2011). “Nuovi archivi e mezzi d'analisi per i testi poetici: i lavori del progetto 'Musisque Deoque'”. In Atti del convegno, Venezia, 21-23 giugno 2010. Amsterdam: Hakkert.

Mc GANN, J.J. (2005). "Culture and Technology: The Way We Live Now, What Is to Be Done?". New Literary History, 36.1, 71-82.

MOSCA, L. and MUSSO, S. (2016). "Costruire una biblioteca digitale di testi latini tardoantichi: problemi e scelte". In L'italiano elettronico. Vocabolari, corpora, archivi testuali e sonori, 143-160. Firenze: Accademia della Crusca.

MUSSO, S. (2014). "La marcatura di testi latini tardoantichi. Un compromesso ragionevole". Aevum Antiquum, 11, 51-87.

TABACCO, R. (2014). "La tarda antichità latina tra i codici e il web". Aevum Antiquum, 11, 317.

(2016). “La prosa latina pagana tardoantica e la biblioteca digitale DigilibLT". In L'italiano elettronico. Vocabolari, corpora, archivi testuali e sonori, 125-142. Firenze: Accademia della Crusca.

UNSWORTH, J. (2003). “Tool-Time, or 'Haven't We Been Here Before?'. Ten Years in Humanities Computing". In Transforming Disciplines. The Humanities and Computer Science (Washington DC, January 18, 2003). Retrieved from http://www.people.virginia/ninch.03.html on 20/04/2017. 